\title{
PENGARUH FASILITAS KAMPUS TERHADAP MOTIVASI DAN PRESTASI MAHASISWA
}

\author{
Nesi Anti Andini ${ }^{1 *}$, Resti Septikasari ${ }^{2}$ \\ ${ }^{1}$ STKIP Nurul Huda Sukaraja \\ "E-mail: nesiaa@stkipnurulhuda.ac.id
}

\begin{abstract}
Abstrak
Penelitian ini bertujuan untuk mengetahui pengarug fasilitas kampus terhadap motivasi dan prestasi Mahasiswa. Metode yang digunakan adalah metode survey. Dimana penelitian survei digunakan untuk mendapatkan data dari tempat tertentu yang alamiah (bukan buatan), tetapi peneliti melakukan perlakuan dalam pengumpulan data, misalnya dengan mengedarkan kuesioner, test, wawancara terstruktur dan sebagainya. Dari hasil menunjukkan nilai sig. $<0,05$. Dengan demikian dapat disimpulkan bahwa terdapat pengaruh yang signifikan antara fasilitas kampus terhadap motivasi dan prestasi belajar Mahasiswa STKIP Nurul Huda.
\end{abstract}

Kata kunci: Fasilitas kampus, Motivasi, Prestasi

\section{PENDAHULUAN}

Pendidikan nasional berfungsi mengembangkan kemampuan dan membentuk watak serta peradaban bangsa yang bermartabat dalam rangka

mencerdaskan bangsa. Pendidikan tidak bisa dilepaskan dari kehidupan manusia. Pada hakekatnya,pendidikan adalah sebuah proses transformasi nilai-nilai yang membangun sikap dan mental serta kualitas individu bangsa untuk berfikir lebih handal sehingga lahirpribadi-pribadi yang mampu memenuhi kebutuhan masyarakat. Pendidikan merupakan sarana dalam upaya meningkatkan kualitas sumber daya manusia dalam pembangunan bangsa indonesia kedepannya. Pendidikan yang

bermutu tinggi akan menghasilkan sumber daya manusia yang berkualitas, handal,

mampu bersaing, dan siap menghadapi segala permasalahan.

Dalam hal ini masyarakat semakin selektif dalam memenuhi kebutuhan, salah satunya dalam memilih lembaga pendidikan sebagai tempat untuk menimba ilmu. Masyarakat mengharapkan lembaga pendidikanyang berkualitas baik. Kepuasanmasyarakat sebagai konsumenpendidikan akan terpenuhi jikalembaga pendidikan selaku penyedialayanan memberikan layanan yang sebanding bahkan melebihi harapan.

Lembaga pendidikan dipandang baik jika kinerja Sumber Daya Manusia (SDM), sarana prasarana dan atmosfer akademik baik. Peserta didik akan merasa puas jika kinerja lembaga pendidikan bekerja dengan baik, yaitu sesuai dengan yang diharapkan. kinerja perguruan tinggi akan berjalan dengan baik jika ditunjang dengan sarana dan prasarana ataufasilitas yang baik untuk proseskegiatan belajar mengajar. fasilitas memainkan peran penting dalam aktualisasi tujuan dan sasaran pendidikan dengan memenuhikebutuhan fisik dan emosional daristaf dan mahasiswa di kampus.

Dimyati dan mudjiono mengemukakan bahwa "fasilitas belajar merupakan sarana dan prasarana pembelajaran. Prasana meliputi gedung sekolah, ruang belajar, lapangan olahraga, ruang ibadah, ruang kesenian dan peralatan olaharaga. Sarana pembelajaran meliputi buku pelajaran, buku bacaan, alat dan fasilitas laboratorium sekolah dan berbagai media pembelajaran yang lain. Dengan adanya fasilitas belajar yang memadai di kampusmahasiswa akan lebih mudah dalam mengerjakan kegiatan-kegiatan yang berhubungan dengan kegiatan

belajarnya di kampus.

Fasilitas merupakan salah satu faktor yang penting dalam kegiatan belajar mengajar, peserta 
didik dapat belajar lebih baik dan menyenangkan apabila sekolah dapat memenuhi segala kebutuhan belajar anak. Kegiatan belajar mengajar akan berjalan lancar apabila didukung dengan fasilitas yang memadai guna tercapainya

pembelajaran yang efektif. Maka kampus perlu menyediakan fasilitas belajar yang dapat menunjang terlaksananya proses pendidikan dan peningkatan kualitas pendidikan. Fasilitas tersebut dapat berupa sarana dan prasarana yang menunjang dan dapat membantu peserta didik untuk menemukan berbagai pengetahuan yang dibutuhkan serta mendorong peserta didik untuk aktif melibatkan diri dalam proses pembelajaran. Fasilitas sangat menunjang berjalannya kegiatankegiatan yang dapat mempengaruhi motivasi dan prestasi mahasiswa. Sebab, dengan fasilitas yang memadai dapat mewadahi kegiatan mahasiswa di kampus sehingga dapat

mempengaruhi motivasi dan prestasi mahasiswa.

Motivasi adalah perubahan energi dalam diri seseorang yang ditandai dengan munculnya

"feeling" dan didahului dengan tanggapan terhadap adannya tujuan.

Motivasi sangat di perlukan dalam proses pembelajaran sebab seseorang yang tidak mempunyai motivasi dalam belajar, akan merasa kesulitan dalam mencapai tujuan. Hal ini merupakan pertanda bahwa sesuatu yang akan di kerjakan itu tidak menyentuh kebutuhannya. Segala Sesuatu yang menarik minat orang lain belum tentu menarik minat orang tertentu selama sesuatu itu tidak bersentuhan dengan kebutuhannya.

Motivasi merupakan daya penggerak terjadinya kelangsungan kegiatan belajar dan memberikan arah pada kegiatan belajar sehingga tujuan yang diinginkan dapat terpenuhi. Dengan demikian motivasi sangat berpengaruh terhadap prestasi. Apabila seseorang tidak mempunyai motivasi untuk belajar, maka orang tersebut tidak akan mencapai prestasi yang optimal. Untuk dapat belajar dengan baik diperlukan proses dan motivasi yang baik pula, memberikan motivasi kepada mahasiswa berarti menggerakan seseorang agar ia dapat termotivasi untuk dalam menggapai tujuan.

Maka dari itu dengan kurangnya fasilitas belajar yang ada dikampus hasil belajar mahasiswa akan menurun untuk itu pihak kampus dituntut agar fasilitas di kampus dapat mengupayakan fasilitas yang memadai dan tentunya mahasiswa akan lebih semangat menerima pelajaran didalam kelas dan termotivasi untuk belajar lebih giat lagi agar mencapai prestasi yang lebih bagus.

Berdasarkan uraian di atas dapat kita ketahui betapa pentingnya fasilitas kampus terhadap motivasi dan prestasi mahasiswa.. namun hal tersebut masih perlu dibuktikan secara ilmiyah, oleh sebab itu peneliti melakukan penelitian dengan mengambil judul "Pengaruh Fasilitas Kampus Terhadap Motivasi Dan Prestasi Mahasiswa".

\section{METODE/EKSPERIMEN}

\section{A. PERENCANAAN PENELITIAN}

\section{Pendekatan Penelitian}

Penelitian ini menggunakan jenis penelitian survei. Dimana penelitian survei digunakan untuk mendapatkan data dari tempat tertentu yang alamiah (bukan buatan), tetapi peneliti melakukan perlakuan dalam pengumpulan data, misalnya dengan mengedarkan kuesioner, test, wawancara terstruktur dan sebagainya. (Sugiono: 12)

\section{Jenis Penelitian}

Jenis penelitian ini adalah korelasional. Penelitian korelasi adalah penelitian yang melibatkan hubungan satu atau lebih variabel lain yang terjadi pada satu kelompok. Pada penelitian ini melibatkan satu variabel independen dan dua variabel dependen.

\section{B. LOKASI PENELITIAN}

Dalam penelitian ini lokasi yang digunakan dalam penelitian adalah kampus STIKIP Nurul Huda Sukaraja. 


\section{TEKNIK PENGUMPULAN DATA}

Teknik pengumpulan data merupakan cara yang digunakan peneliti untuk memperoleh data agar nantinya diperoleh data-data yang sesuai dengan masalah yang diteliti. Teknik pengumpulan data yang digunakan dalam penelitian ini antara lain:

1. Angket (koesioner)

Angket merupakan teknik pengumpulan data yang dilakukan dengan memberikan seperangkat pertanyaan atau pernyataan tertulis kepada responden atau dijawab. Metode ini memuat sejumlah pertanyaan atau pernyataan yang diajukan secara tertulis kepada siswa untuk memperoleh data tentang keterampilan menadakan variasi media pembelajaran dan keterampilan menjelaskan. Dalam penelitian ini pengisian angket dilakukan oleh mahasiswa untuk mengetahui pengaruh fasilitas kampus terhadap motivasi dan prestasi mahasiswa.

2. Observasi

Nana Syaodih (2013: 220) mengemukakan bahwa observasi (observation) atau pengamatan merupakan suatu teknik atau cara mengumpulkan data dengan jalan mengadakan pengamatan terhadap kegiatan yang sedang berlangsung. Pengertian lain observasi adalah kegiatan pengamatan (pengambilan data) untuk mengetahui seberapa jauh efek tindakan yang telah mencapai tindakan.

Metode observasi ini dilakukan untuk memperoleh data mengenai motivasi dan prestasi mahasiswa. Untuk mendapatkan data tersebut maka perlu menggunakan lembar observasi motivasi dan prestasi. Dalam hal ini lembar observasi motivasi dan prestasimahasiswa dilakukan oleh beberapa observer.

\section{Dokumentasi}

Metode dokumentasi yaitu metode pengumpulan data melalui catatan, transkip, buku, surat kabar, majalah, prasasti, notulen rapat, agenda dan sebagainya. Metode ini digunkan untuk memperoleh data tentang struktur lembaga, jumlah peserta didik, serta foto ketika penelitian berlangsung.

Analisis data adalah proses mencari dan secara sistematis data yang diperoleh dari hasil tes, catatan lapangan, dokumentasi dengan cara mengorganisasikan data kedalam unit, melakukan sintesa, menyusun kedalam pola, memilih mana yang penting dan mana yang akan dipelajari dan membuat kesimpulan sehingga mudah dipahami oleh diri 
sendiri maupun orang lain.

Penelitian ini adalah penelitian korrelation atau hubungan yang datanya berbentuk interval atau ratio satu variabel independen dan dua variabel dependen sehingga dalam penelitian ini tahapan pengambilan data secara statistik inferensial

adalah:

1. Uji Validitas

Menurut suharsimi validitas adalah suatu ukuran yang menunjukan tingkattingkat kevalidan atau keshahihan suatu instrumen. Uji validitas dapat dilakukan dengan melalui uji coba alat ukur kepada responden. Suatu instrumen dikatakan valid atau shahih adalah instrumen yang mempunyai validitas tinggi.

Begitu pula sebaliknya, suatu instrumen dikatakan tidak valid adalah intrumen yang memiliki validitas rendah. Valid tidaknya suatu item instrumen dapat diketahui dengan membandingkan indeks korelasi product moment person dengan nilai signifikasi 5\% dengan kritisnya atau dengan kata lain dapat dibandingkan antara $r$ hitung dengan $r$ tabel.

Uji validitas tiap butir dengan rumus sebagai berikut:

$$
\text { r hitung den! }(\square)(\square) \text { l. }
$$

liditas tiap butir dengan rumus seb gai br

$$
\begin{aligned}
& \frac{\left.\left.\square N \sum X(\square)\right)(\square X)(\Sigma Y)(\square)\right)}{\sqrt{N \sum X 2-\left(\sum X^{\prime} 2\right)(N \Sigma Y 2-(\Sigma Y n 2)}} \\
& \mathrm{rXY} \quad= \\
& \text { Keterangan: } \\
& r \mathrm{xy} \quad=\text { koefisien korelasi product moment } \\
& \mathrm{uX} \quad=\text { jumlah skor dalam sebaran } \mathrm{X} \\
& \Delta \mathrm{X}_{2} \quad=\text { jumlah skor yang dikuadratkan dalam sebaran } \\
& \mathrm{X} \\
& =\text { jumlah skor dalam sebaran } \mathrm{Y} \\
& \text { QY = jumlah skor yang dikuadratkan dalam sebaran } \\
& \square Y_{2} \quad \mathrm{Y} \\
& \square X Y=\text { jumlah hasil kali skor } X \text { dan } Y \text { yang berpasangan } \\
& \mathrm{N} \quad=\text { jumlah sampel }
\end{aligned}
$$

2. Uji Reliabilitas

Suharsimi juga mengatakan bahwa reliabilitas menunjukan pada satu 
pengertian bahwa suatu instrumen cukup dapat dipercaya untuk digunakan sebagai alat pengumpulan data karena instrumen tersebut sudah baik. Untuk mengatahui reabilitas dari instrumen tentang fasilitas kampus terhadap mitivasi dan prestasi mahasiswa, maka peniliti menggunakan rumus alpha cronbach's.

3. Uji Normalitas

Uji normalitas digunakan untuk mengetahui populasi data berdistribusi normal atau tidak. Dalam penelitian ini uji normalitas bertujuan untuk menguji data variabel bebas $(\mathrm{X})$ dan variabel terikat $(\mathrm{Y})$ pada persamaan regresi yang dihasilkan, apakah berdistribusi normal atau berdristribusi tidak normal. Bila data menyebar data menyebar di sekitar garis diagonal dan engikuti arah garis diagonal, maka model regresi memenuhi asumsi normalitas, dan sebaliknya.

4. Uji Hipotesis

Menurut sujiono (2010: 190) uji hipotesis ini digunakan untuk mencari korelasi antara variabel $X$ dengan variabel $Y 1$ dan variabel $X$ dengan veriabel $Y 2$. Dalam penelitian ini, peneliti meggunakan regresi linier sederhana untuk mengestimesi besarnya koefisien-koefisien yang dihasilkan dari persamaan yang bersifat linier, yang melibatkan satu variabel independen dan satu veriabel dependen, yaitu untuk mengukur antara variabel $X$ dengan variabel $Y .1$ dan variabel $X$ dengan veriabel $Y .2$ dan seberapa besar kontribusi yang diterangkan oleh variabel $X$ dengan variabel Y.1 dan variabel $X$ dengan veriabel $Y .2$. 


\section{A. Deskrispi Penelitian}

\section{HASIL DAN PEMBAHASAN}

Penelitian ini dilakukan kampus STKIP Nurul Huda. Kampus ini terdapat diberbagai tepat, yaitu Kmapus A dan B terletak di Sukaraja sedangkan kampus C terletak di Tanah Merah. Tujuan dilaksanakannya penelitian ini adalah untuk mengetahui pengaruh fasilitas kampus terhadap motivasi dan prestasi belajar mahasiswa PGMI. Dalam penelitian ini peneliti mengambil populasi sejumlah Mahasiswa PGMI dari semester terendah sampai tertinggi. Sedangkan sampel dalam penelitian ini adalah Mahasiswa PGMI Kampus C1 semester V yang berjumlah 22 mahasiswa.

Data dalam penelitian ini diperoleh peneliti dari pemberian angket, observasi, wawancara dan dokumentasi. Pemberian angket fasilitaskampus dan motivasi dilakukan peneliti pada mahasiswa PGMI semester V. Selanjutnya, metode observasi dilakukan peneliti untuk mengamati proses kegiatan dalam pembelajaran, dan juga mengamati mengenai fasilitas kampus yang ada di STKIP Nurul Huda. Dalam memperoleh data hasil belajar Mata Kuliah metodologi Pembelajaran akidah akhlak, peneliti mengambil data dari hasil akhir ujian yang diperoleh dari Dosen pengampu mata kuliah.

\section{B. Keadaan Fasilitas Kampus}

Untuk menyelenggarakan suatu pendidikan, tentunya memerlukan fasilitas yang memadai dalam rangka melancarkan proses pembelajaran. Fasilitas tersebut dapat berupa fisik maupun nonfisik. Sehingga agar menjadi lembaga pendidikan yang lebih baik secara kualitas dituntut akan fasilitas yang lengkap dalam rangka pemenuhan kebutuhan mahasiswa yang sangat diperlukan. Adapun sarana dan prasarana yang ada yaitu:

1. Keadaan Bangunan

Bangunan atau sarana dan prasarana merupakan hal yang sangat penting dalam sebuah pendidikan. Karena fasilitas tersebut digunakan dalam proses belajar mengajar yang berguna demi kelangsungan proses pembelajaran. Dibawah ini akan dipaparkan mengenai data sarana dan prasarana yang ada di STKIP Nurul Huda.

2. Keadaan Fasilitas kampus

a. Gedung merupakan milik sendiri 
b. Sarana pembelajaran yang sudah ada dapat digunakan secara maksimal. Meja, kursi, papan tulis, dan alat tulis sudah tersedia dengan cukup untuk kegiatan belajar mengajar di kelas.

c. Laboratorium Komputer, Bahasa dan Fisika yang sudah memadai, sehingga bisa digunakan maksimal oleh semua siswa untuk melakukan praktikum.

d. Ruang Perpustakaan trebagi menjadi dua yaitu yang pertama terletak di kampus A dan kedua di kampus $\mathrm{C}$.

e. Tempat Ibadah atau Mushola sudah ada dan sudah dimanfaatkan untuk kegiatan keagamaan antara lain untuk sholat berjamaah pada waktu sholat dhuhur dan membaca Al-Quran.

f. Ruang Micro Teaching yang memadai

g. Lapangan Olah Raga yang cukup untuk digunakan beberbagai kegiatan, misalnya kemah dan acara pengajian.

\section{B. Penyajian Data}

Dibawah ini adalah data perolehan dari penyebaran angket fasilitas kampus, motivasi dan perolehan data prestasi belajar UAS mata kuliah metodologi pembelajaran akidah akhlak yang diperoleh dari mahasiswa PGMI semester V.

d) Analisis Regresi Sederhana untuk Menghitung Pengaruh Fasilitas Belajar terhadap Motivasi Belajar

\section{Tabel 8}

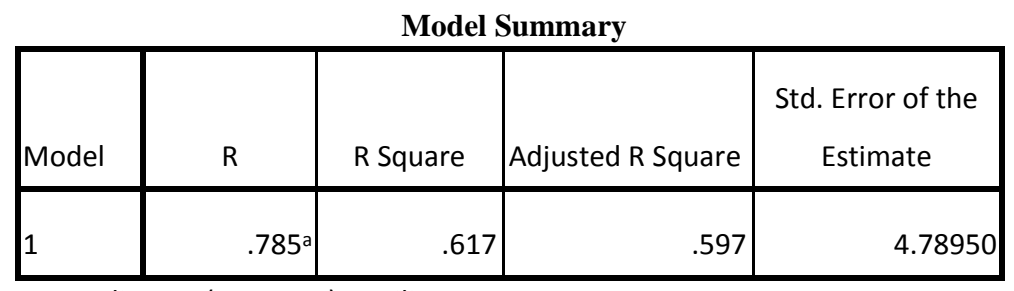

a. Predictors: (Constant), Fasilitas Kampus

Tabel ini menampilkan nilai R yang merupakan symbol dari nilai koefesien korelasi. Nilai korelasi pada tabel tersebut adalah 0,785. Nilai ini dapat diinterpretasikan bahwa hubungan kedua variable penelitian dikategorikan tinggi. 
Tabel 9

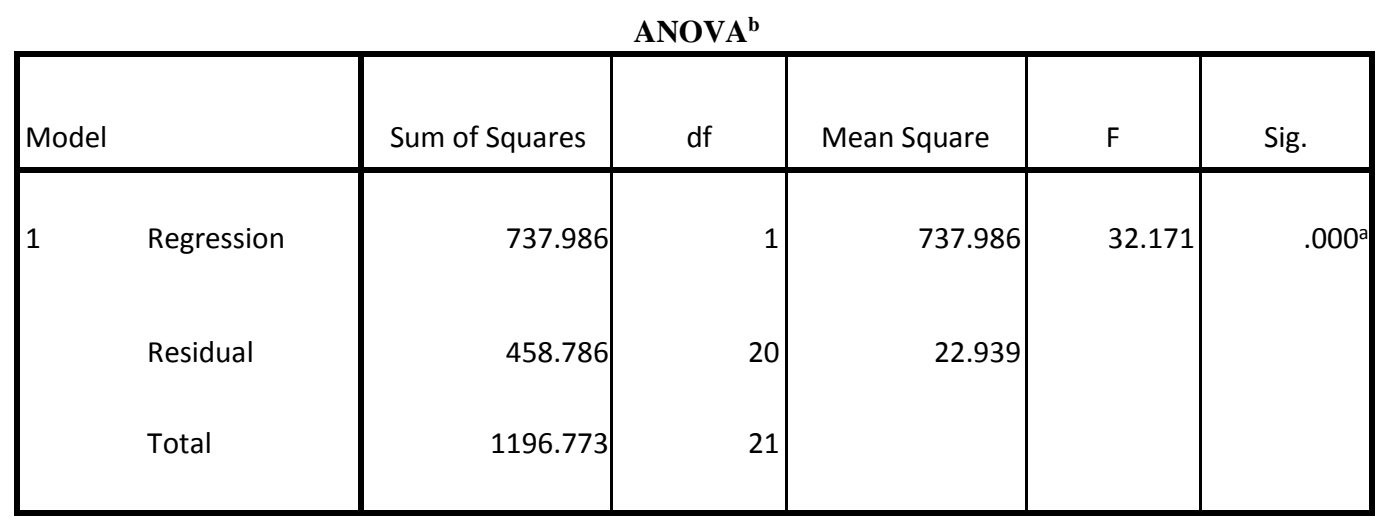

a. Predictors: (Constant), Fasilitas Kampus

b. Dependent Variable: Motivasi Belajar

Tabel ini digunakan untuk menentukan taraf signifikansi atau linieritas dari regresi.

Kriterianya dapat berdasarkan uji F atau uji nilai signifikansi (Sig.) dengan ketentuan jika nilai Sig. $<0,05$, maka model regresi adalah linier dan berlaku sebaliknya. Pada tebal ini diperoleh nilai Sig. sebesar 0,000 yang berarti $<$ dari

0.05 , dengan demikian model persamaan regresi berdasarkan data penelitian adalah

Tabel 10

\begin{tabular}{|c|c|c|c|c|c|}
\hline \multirow[b]{2}{*}{ Model } & \multicolumn{2}{|c|}{ Unstandardized Coefficients } & \multirow{2}{*}{$\begin{array}{c}\begin{array}{c}\text { Standardized } \\
\text { Coefficients }\end{array} \\
\text { Beta }\end{array}$} & \multirow[b]{2}{*}{$\mathrm{t}$} & \multirow[b]{2}{*}{ Sig. } \\
\hline & B & Std. Error & & & \\
\hline 1 (Constant) & 34.285 & 6.324 & & 5.422 & .000 \\
\hline Fasilitas Kampus & .560 & .099 & .785 & 5.672 & .000 \\
\hline
\end{tabular}

a. Dependent Variable: Motivasi Belajar

Dari tabel diatas diperoleh data bahwa taksiran nilai parameter dari regresi linier sederhana dengan hubungan $\mathrm{X}$ mempengaruhi Y:

$a=34.285 b$

$=0,560$

Sehingga model taksiran regresi linier sederhana adalah:

$Y=a+b X$

$Y=34.285+0,560 X$

Berdasarkan tabel mode summary diatas diperoleh nilai rhitung 0,785 . Pada taraf 
signifikasi 5\% untuk jumlah responden (N) sebanyak 22 diperoleh nilai rtabel sebesar 0 , 234. Karena rhitung > rtabel maka Ho ditolak dan $\mathrm{Ha}$ diterima sehingga dapat disimpulkan bahwa "Ada pengaruh yang signifikan antara fasilitas belajar terhadap motivasi belajar mnahasiswa PGMI STKIP Nurul Huda".

e) Analisis Regresi Sederhana untuk Menghitung Pengaruh Fasilitas Belajar terhadap Prestasi Belajar

\section{Tabel 11}

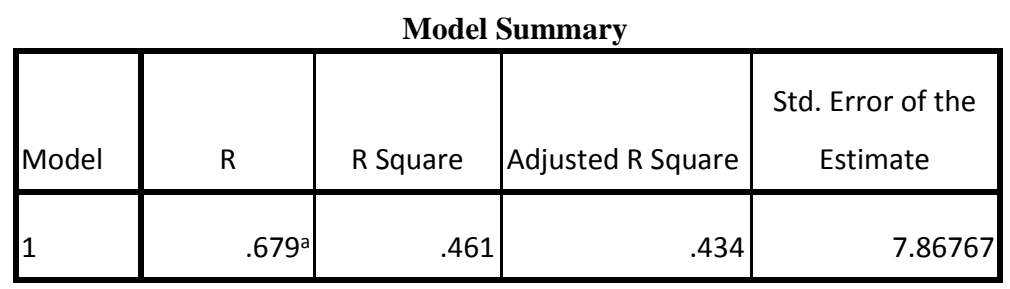

a. Predictors: (Constant), Fasilitas Kampus

Tabel ini menampilkan nilai R yang merupakan symbol dari nilai koefesien korelasi. Nilai korelasi pada tabel tersebut adalah 0,679. Nilai ini dapat diinterpretasikan bahwa hubungan kedua variable penelitian dikategorikan tinggi

Tabel 12

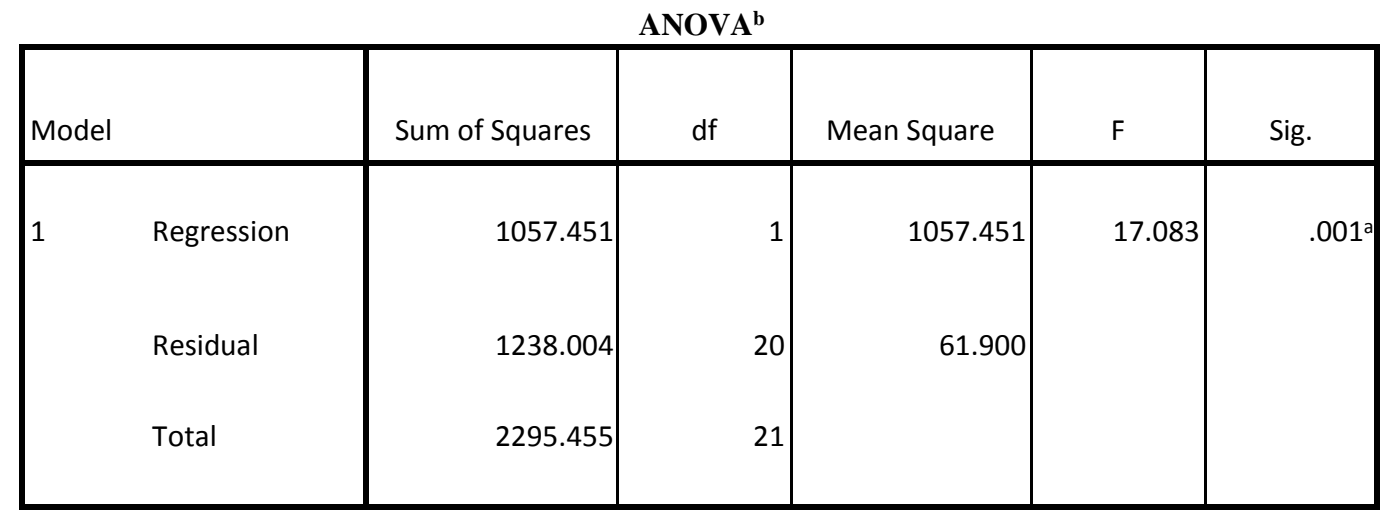

a. Predictors: (Constant), Fasilitas Kampus

b. Dependent Variable: Prestasi Belajar

Tabel ini digunakan untuk menentukan taraf signifikansi atau linieritas dari regresi.

Kriterianya dapat berdasarkan uji F atau uji nilai signifikansi (Sig.) dengan ketentuan jika nilai Sig. 0,05, maka model regresi adalah linier dan berlaku sebaliknya. Pada tebal ini diperoleh nilai Sig. sebesar 0,001 yang berarti < dari 0,05, dengan demikian model persamaan regresi berdasarkan data penelitian adalah signifikan. 
Tabel 13

\begin{tabular}{|c|c|c|c|c|c|c|}
\hline \multicolumn{7}{|c|}{ Coefficients $^{\mathrm{a}}$} \\
\hline \multirow[b]{2}{*}{ Mode } & & \multicolumn{2}{|c|}{$\begin{array}{l}\text { Unstandardized } \\
\text { Coefficients }\end{array}$} & Standardized Coefficients & \multirow[b]{2}{*}{$\mathrm{t}$} & \multirow[b]{2}{*}{ Sig. } \\
\hline & & B & Std. Error & Beta & & \\
\hline \multirow[t]{2}{*}{1} & (Constant) & 37.174 & 10.388 & & 3.579 & .002 \\
\hline & Fasilitas Kampus & .671 & .162 & .679 & 4.133 & .001 \\
\hline
\end{tabular}

a. Dependent Variable: Prestasi Belajar

Dari tabel diatas diperoleh data bahwa taksiran nilai parameter dari regresi linier sederhana dengan hubungan $\mathrm{X}$ mempengaruhi $\mathrm{Y}$ :

$a=37.174$

$b=0,671$

Sehingga model taksiran regresi linier sederhana adalah:

$Y=a+b X$

$Y=37.174+0,671 X$

\section{f) Uji Manova untuk Menghitung Pengaruh Fasilitas Belajar terhadap}

\section{Motivasi dan Prestasi Belajar}

Uji Manova adalah bentuk multivariate dari analysis of Variance (ANOVA) merupakan uji yang dilakukan untuk pengujian satu variabel independent yaitu fasilitas kampus $(X)$ terhadap dua atau lebih variabel dependent yaitu motivasi belajar (Y1) dan prestasi belajar (Y2). Adapun data tersebut dapat dilihat dari perbandingan nilai angket dari fasilitas kampus dan motivasi belajar serta dari nilai Metodologi Pembelajaran Akidah Akhlak Mahasiswa PGMI semester V.. Dibawah ini hasil dari uji manova adalah sebagai berikut: 


\section{Tabel 14}

Pengaruh Fasilitas Belajar terhadap Motivasi dan Hasil Belajar

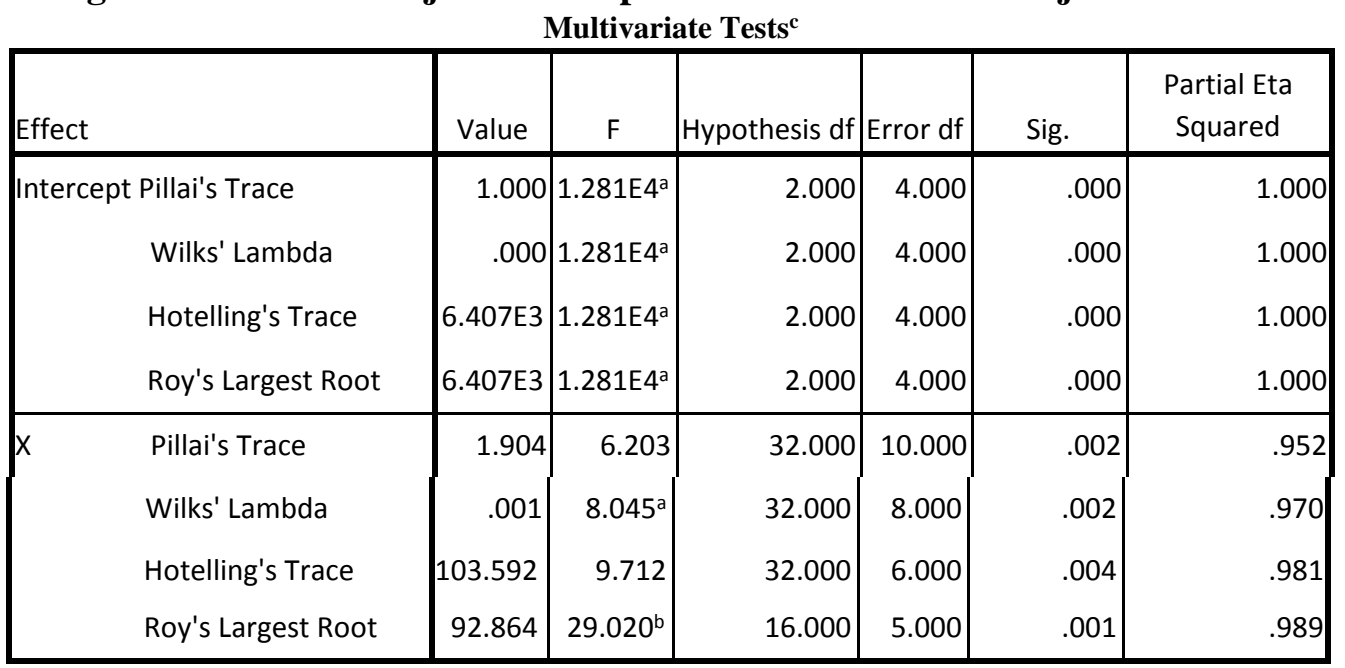

a. Exact statistic

b. The statistic is an upper bound on $\mathrm{F}$ that yields a lower bound on the significance level.

c. Design: Intercept $+\mathrm{X}$

Dari hasil uji Multivariate test dapat dilihat bahwa pada kolom sig. hasil yang telah diperoleh pada kolom $X$, menunjukkan nilai sig. $<0,05$. Dengan demikian dapat disimpulkan bahwa terdapat pengaruh yang signifikan antara fasilitas kampus terhadap motivasi dan prestasi belajar Mahasiswa STKIP Nurul Huda. 


\section{PENUTUP}

a. Berdasarkan tabel mode summary diatas diperoleh nilai rhitung 0,785. Pada taraf signifikasi 5\% untuk jumlah responden $(\mathrm{N})$ sebanyak 22 diperoleh nilai rabel sebesar 0 , 234. Karena rhitung $>$ rtabel maka $\mathrm{Ho}_{0}$ ditolak dan $\mathrm{H}_{a}$ diterima sehingga dapat disimpulkan bahwa "Ada pengaruh yang signifikan antara fasilitas belajar terhadap motivasi belajar mnahasiswa PGMI STKIP Nurul Huda."

b. Berdasarkan tabel mode summary diatas diperoleh nilai rhitung 0,679. Pada taraf signifikasi $5 \%$ untuk jumlah responden (N) sebanyak 22 diperoleh nilai rtabel sebesar 0 , 234. Karena rhitung $>$ rtabel maka $\mathrm{H}_{0}$ ditolak dan $\mathrm{H}_{a}$ diterima sehingga dapat disimpulkan bahwa "Ada pengaruh yang signifikan antara fasilitas belajar terhadap prestasi belajar mahasiswa PGMI STKIP Nurul Huda."

c. Dari hasil menunjukkan nilai sig. < 0,05. Dengan demikian dapat disimpulkan bahwa terdapat pengaruh yang signifikan antara fasilitas kampus terhadap motivasi dan prestasi belajar Mahasiswa STKIP Nurul Huda.

\section{UCAPAN TERIMAKASIH}

\section{DAFTAR PUSTAKA}

Arikunto, S. 2006. Prosedur Penelitian Suat Pendekatan Praktik, Edisi Revisi VI. Jakarta: Rineka Cipta.

Dimyati dan Mudjiono. 2010. Belajar dan Pembelajaran. Jakarta: Rineka Cipta.

Nana, Syaodih, Sukmadinata.2013. Metode Penelitian Pendidikan. Bandung: Remaja Rosdakarya.

Purwanto,Ngalim. 2006. Psikologi Pendidikan. Bandung: Remaja

Soleman, zuhria.Pdf. "pengaruh fasilitas belajar terhadap motivasi belajar siswa kelas x pada

mata pelajaran ekonomi ma nurul yaqin kota gorontalo" 